\title{
Seismic hazard analysis of Sinop province, Turkey using probabilistic and statistical methods
}

\author{
Recai Feyiz Kartal ${ }^{1}$, GÜnay Beyhan ${ }^{2, *}$ and Ayhan Keskinsezer ${ }^{2}$ \\ ${ }^{1}$ Earthquake Department, Prime Ministry Disaster and Emergency Management Presidency, Ankara, Turkey. \\ ${ }^{2}$ Department of Geophysical Engineering, Sakarya University, Adapazarl-Sakarya 54187, Turkey. \\ ${ }^{*}$ Corresponding author. e-mail: gbeyhan@sakarya.edu.tr
}

Using 4.0 and greater magnitude earthquakes which occurred between 1 January 1900 and 31 December 2008 in the Sinop province of Turkey this study presents a seismic hazard analysis based on the probabilistic and statistical methods. According to the earthquake zonation map, Sinop is divided into first, second, third and fourth-degree earthquake regions. Our study area covered the coordinates between $40.66^{\circ}-42.82^{\circ} \mathrm{N}$ and $32.20^{\circ}-36.55^{\circ} \mathrm{E}$. The different magnitudes of the earthquakes during the last 108 years recorded on varied scales were converted to a common scale (Mw). The earthquake catalog was then recompiled to evaluate the potential seismic sources in the aforesaid province. Using the attenuation relationships given by Boore et al. (1997) and Kalkan and Gülkan (2004), the largest ground accelerations corresponding to a recurrence period of 475 years are found to be $0.14 \mathrm{~g}$ for bedrock at the central district. Comparing the seismic hazard curves, we show the spatial variations of seismic hazard potential in this province, enumerating the recurrence period in the order of 475 years.

\section{Introduction}

Considering the development and improvement activities in recent years, Sinop province has become a host to important projects for Turkey. It is one of the most populated cities in the country and hosts Turkey's first nuclear power plant in the region. Thus, construction activities need to be done as reliably as the seismic hazard of region permits (figure 1). The most important seismic activity which could affect the area is right directional North Anatolian Fault Zone (NAFZ). NAF which is one of the most important strike-slip fault systems known in the world has close resemblance with San Andreas Fault at California, USA. When the epicenter map covering the years 1900-2011 was examined, Sinop is shown in the highly active regions of the country.
Since earthquake occurrence cannot be prevented,governments and organizations should work towards minimizing the damage caused by earthquakes. The most important work in order to reduce damage is the preparation a seismic hazard map that will serve as a basis for the development of earthquake-resistant construction techniques. For setting the parameters for designing earthquake-resistant structures, using the probabilistic and statistical methods for determining seismic hazard estimation will be important and useful. In this study, we aimed at determining the seismic hazards in the Sinop province using the probabilistic and statistical methods.

Probabilistic Seismic Hazard Analysis (PSHA) is an estimate of exceedance probability in a given time period about levels of ground motion at different locations. The first step in establishing a

Keywords. Turkey; seismic hazard; North Anatolian Fault; probabilistic. 


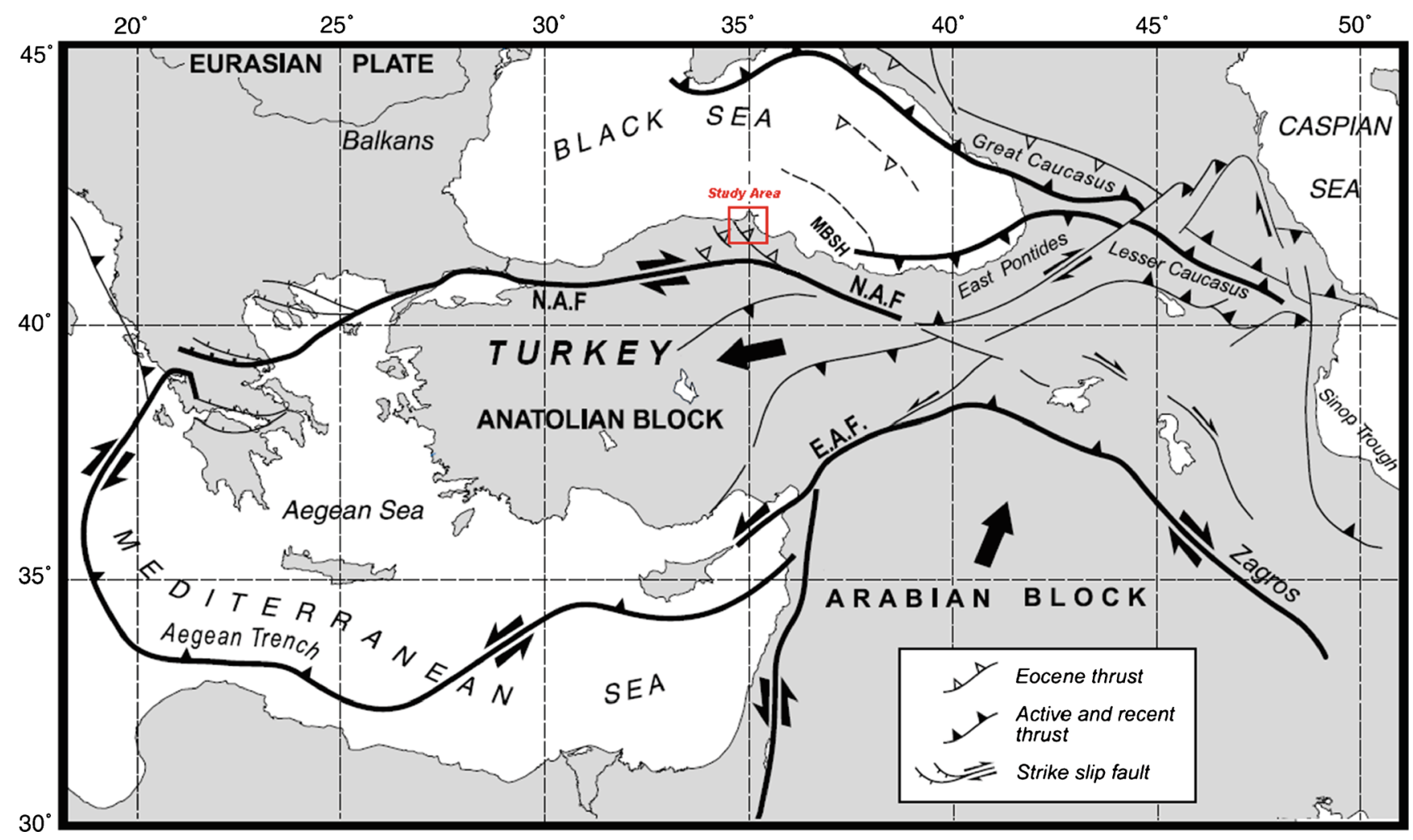

Figure 1. Tectonic sketch of the Arabia/Eurasia collision zone. Eastern Black Sea basin is located directly north of the tectonic escape of Anatolia. Dotted frame indicates the surveyed area. MBSH: Mid Black Sea High, NAF: North Anatolian Fault, EAF: East Anatolian Fault. Thick black arrows indicate motion of main crustal blocks with respect to Eurasia (modified from Rangin et al. 2002).

reliable earthquake catalog is to compile records of earthquakes from past years and examine the tectonic structure. The seismicity parameters of source zones and earthquake forming capacities can be calculated by checking every record from earthquake source zones in the study area. Attenuation relationships are important parameters for the calculation of the hazard analysis. More than one attenuation relationships were used in this study. This helped us to compare the obtained results.

Seismic hazard analysis can be done in two waysDeterministic Seismic Hazard Analysis (DSHA) and the PSHA. In this study, PSHA was used. The first step of the DSHA approach is the determination of the biggest earthquake that occurred in the past from the seismic sources in the study area. If the earthquake catalog is not old enough or if there are some deficiencies in the catalog then the value of the biggest earthquake can be increased to 0.54 units. The second step is to select the most appropriate attenuation relationship that fits the characteristics of the region. Largest ground acceleration constituted on the bedrock at the project area caused by the biggest earthquake in terms of instrumental magnitude on the seismic source located a certain distance from the project area is calculated by attenuation relationships (Abrahamson and Silva 1997; Sadigh et al. 1997). Many such seismic hazard studies are available today.

Ogata (1988) discussed several classes of stochastic models to study the origin and magnitudes of earthquakes. This study selects a statistical model for the standard activity of earthquake series by comparing several possible models using likelihood methods. In the next section, some possible stochastic models for seismic activity derived from empirical studies, mainly of aftershock statistics, are reviewed and discussed.

The Epidemic Type Aftershock-Sequences (ETAS) model is a point process representing the temporal activity of earthquakes in a certain geophysical region for which a method for fast and accurate computation of data is required. The present numerical procedures put the parameter estimation of the ETAS model to practical use in a large number of occurrence records (Bansal and Ogata 2010; Ogata 2011; Bansal et al. 2012).

The basis of statistical methods for the determination of seismic hazards was first developed by Cornell (1968). Previously, only the least squares regression analyses were used (Chiaruttini and 
Siro 1981; Johnston 1996; Giardini et al. 1997; Gasperini and Ferrari 2000). However, a number of methods have been developed later. In our knowledge, the first general orthogonal regression (GOR) method to be applied to magnitude conversions is the Chi-square regression (CSQ), proposed by Stromeyer et al. (2004). Lolli and Gasperini (2012) provide a comparison among general orthogonal regression methods applied to earthquake magnitude conversions. Such conversions were usually done by empirical regressions using the ordinary least squares method (e.g., Chiaruttini and Siro 1981; Johnston 1996; Giardini et al. 1997; Gasperini and Ferrari 2000), which assumes that the uncertainty of the independent variable is negligible, and by the simple orthogonal regression approach (Ambraseys 1990; Gutdeutsch et al. 2002), which assumes that both variables have the same uncertainty. As such, assumptions are not fully appropriate for magnitude data sets, the use of GOR methods, which assume a different uncertainty for each of the two variables, are generally preferable. There are strict analogies among these three methods even though their formulations may appear quite different (Lolli and Gasperini 2012).

Turkey is an important area in terms of seismic risk. For this reason, a large number of seismic risk analyses must be conducted in the central settlement areas. In a study in the Antalya region, time and space windows proposed by Deniz and Yücemen (2005) for earthquakes with moment magnitudes $\geq 4.5$, were used. As described by Deniz and Yücemen (2005), the earthquakes that fall into the space and time windows defined for the magnitude level of a preceding earthquake with larger magnitude are classified as aftershocks of this event. If a larger magnitude earthquake occurs in a later time and space window of a smaller magnitude earthquake, this event is classified as the foreshock of the larger magnitude earthquake. To implement the space and time windows proposed by Deniz and Yücemen (2005) and Deniz (2006), the magnitudes of earthquakes in the whole catalog should be converted to moment magnitude scale. This is achieved by using the equation derived by Deniz (2006) based on earthquakes recorded in Turkey. In a similar study, earthquake risk in the Eskişehir region was estimated using the stochastic methods by Genç (2004).

Studies have been conducted using different seismic hazard assessment approaches (i.e., deterministic and probabilistic), different attenuation relationships, and different models for seismic sources, magnitude distribution, and the time of earthquake occurrence. Two different methods are widely used for describing earthquake ground motions in geotechnical engineering. Both probabilistic and deterministic methods have a role in hazard and risk analyses performed for decisionmaking purposes. PSHA has allowed uncertainties in size, location, and rate of recurrence of earthquakes, as well as in the variation of ground motion characteristics with earthquake size and location, to be explicitly considered in the evaluation of seismic hazards (Kramer 1996). Also determining the earthquake insurance premium a rate using stochastic methods was made by Deniz (2006). Seismic safety work of underground networks was made by Selçuk and Yücemen (2000). Conversely, earthquake hazard of the Aegean extension region (West Turkey) was made by Polat et al. (2008).

In this study, PSHA methodology based on Cornell (1968) was applied for Sinop city and PGA values $10 \%$ probability of exceedance in 50 years at rock sites were determined by using the attenuation relationships proposed by Boore et al. (1997) and Kalkan and Gülkan (2004). Finally, PGA zonation maps were created for the study area by the CRISIS software (CRISIS 2003) prepared on the basis of Geographic Information System.

\section{Geology and tectonic}

Paleozoic metamorphic rocks constitute the main formations at Sinop. Metamorphic series around the Boyabat and Duraan districts are spread over a wide area on the east and south-west direction. Upper Cretaceous flysch and limestone occur at the south of Türkeli-Gerze line. This segment generally consists of layers of thick sandstone, marl and marly limestone. Eocene flysch series consists of thin-bedded, poorly cemented sandstone and marl around the Ayancik and Erfelek. The Neogene flysch at the Karasu Valley, southwest of the city center, consists of coarse-grained conglomerates and gres. At the west of the Sinop province and north of the Gerze, there are Pleistocene-aged series covering large areas consisting of sand and clay beds. Upper cretaceous volcanic rocks are found in some places at the Cape Sinop (Boztepe) and the northwest of the Boyabat district.

The study area is located at the Pontides, one of Turkey's tectonic units. Pontids are a part of Alpine mountain formation which starts from Czechoslovakia, Carpathians and passes through Romania, Yugoslavia and Bulgaria and eastward along the Black Sea shores to the Little Caucasus, Iran and extending to the Indian platform. According to the theories of plate tectonics, Alpine mountain formation system was formed by the collision of island arcs and continents (Dewey and Bird 1970). Alpine system which is a collision orogenic belt is a result of the extinction of the former Tethys Ocean (Şengör 1982). The island arc series volcanics around the Alpine mountain formation 
was developed throughout this entire belt. Ercan and ve Gedik (1983) and Yilmaz (1980), compiled studies about this island arc volcanism at the Pontids that started from Lias and continued until the upper Eocene in various stages. There are not many studies about the volcanism before the Lower Cretaceous. But volcanics that are younger than Lower Cretaceous have been studied in detail and plenty of data has been obtained. In the Pontides, Upper CretaceousEocene aged volcanic rocks have been thought to descend from a subduction zone dipping to the north by Tokel (1972, 1973, 1977, 1981), Stojanov (1973), Peccerillo and Taylor (1975, 1976), Akın (1978), Gedikoğlu (1978), Eğin and Hirst (1979), Gedikoğlu et al. (1979, 1982), Özsayar et al. (1982), Ercan et al. (1983). In this region an ocean called Tethys Ocean began to open up from Malm (Şengör and Yllmaz 1981) and as a result of the subduction zone that occurred by the plunging of crust material of this ocean's northern branch under the Pontian continent, an island arc volcanism developed after the Upper Cretaceous at the Pontian continent (figure 2).

After the collision between Anatolide-Tauride platform in the south and Pontian continent in the north from the Lower Eocene, this subduction zone completed its evolution (Şengör and Yllmaz 1981). In other words, The North Anatolian Tethys Ocean was closed due to the northern movement of the African and Arabian plates after the Upper Cretaceous (Peccerillo and Taylor 1976; Şengör and Yılmaz 1981; Ercan and ve Gedik 1983). Upper Cretaceous aged Hamsaros volcanics, Çokran associate Yemişliçay formation and Eocene aged Tekkeköy formation volcanics are island arc volcanics that descended from this subduction zone. Thus, Peccerillo and Taylor (1975, 1976) opined that Upper Cretaceous-Eocene aged volcanics at all Pontides that cover the study area too, might have been in the group of island arc volcanism. This was proved to be valid and volcanics in the study area was identified in the group of typical island arc volcanism with the help of chemical analysis of major elements, petrographic studies and regional geodynamic reviews. However, Plio-Quaternary aged Akyörük bazalt which is the youngest volcanism at the region is not in the island arc group unlike other volcanics and is thought to have been formed by the crustal thickening after the collision of Pontian continent and Tauride-Anatolide continets or an entirely alkaline volcanism derived from the primordial mantle. The theory of the mantle uplift in mid-plate is more appropriate for explaining the formation of this type of volcanics. Besides, such volcanics are known to be active in the entire Pontian belt until the Upper Quaternary (Ercan and ve Gedik
1983). This subject will have more clarity in the future when the analyses of trace elements and rare earth elements will be studied on this young alkaline formation.

\section{Active faults in the study area}

Approximately $94 \mathrm{~km}$ long section of NAFZ between the Köprübaşı in the east and Kargı in the west, was examined under the name of KöprübaşıKargı section (Şaroğlu and ve Yılmaz 1987). NAFZ is very distinct between the Ladik and Havza with N70W direction and loses its distinctness $4 \mathrm{~km}$ north of Havza transforming to large number of complex zones (figure 3).

Approximately $9 \mathrm{~km}$ west from this section, it becomes morphologically apparent again near the Köprübaşı. The fault tracks the Kızılırmak valley between the Kamil and Karg. It consists of three sub-sections between the Köprübaşı and Karg1 (Şaroğlu and ve Yılmaz 1987) (figure 3).

Between Köprübaşı and Çaygüneyi, there are many independent fractures with $\mathrm{N} 75 \mathrm{~W}$ trend inside a zone which is $24 \mathrm{~km}$ long and $4 \mathrm{~km}$ wide. This zonal structure is entirely related to ophiolitic units that the fault passed through. Between Çaygüneyi and Alanşeyhi, approximately $37 \mathrm{~km}$ long section is located. There is no detailed information about this section (Şaroğlu and ve Yllmaz 1987). Between Alanşeyhi and Kamil, there is a zone which consists of a few notable $\mathrm{E}-\mathrm{W}$ trending fractures that are approximately $33 \mathrm{~km}$ long. Between Alanşeyhi and Tahtaköprü the fault tracks the Kocaçaydere valley along $14 \mathrm{~km}$. There are different aged lithological units which stand side by side along the fault valley (Şaroğlu and ve Yllmaz 1987). There were 10 earthquakes with their instrumental magnitudes 6.0 or higher in the region (figure 3 ). We limit our study area to the years between 1900 and 2008 as given in table 1 .

\section{The creation of earthquake catalog}

The Republic of Turkey Prime Ministry Disaster and Emergency Management Presidency (RTPMDEMP 2009a) earthquake database and International Seismological Center (2009) records were used for earthquake catalogs. From these records earthquakes that occurred between 1 January 1900 and 31 December 2008 were taken into consideration.

Moment magnitude ( $\mathrm{Mw}$ ) was used in this study. The magnitude of the smallest earthquake that can cause seismic hazard is identified as 4.5 according to moment magnitude. Conversion to Mw scale of earthquake records which different 


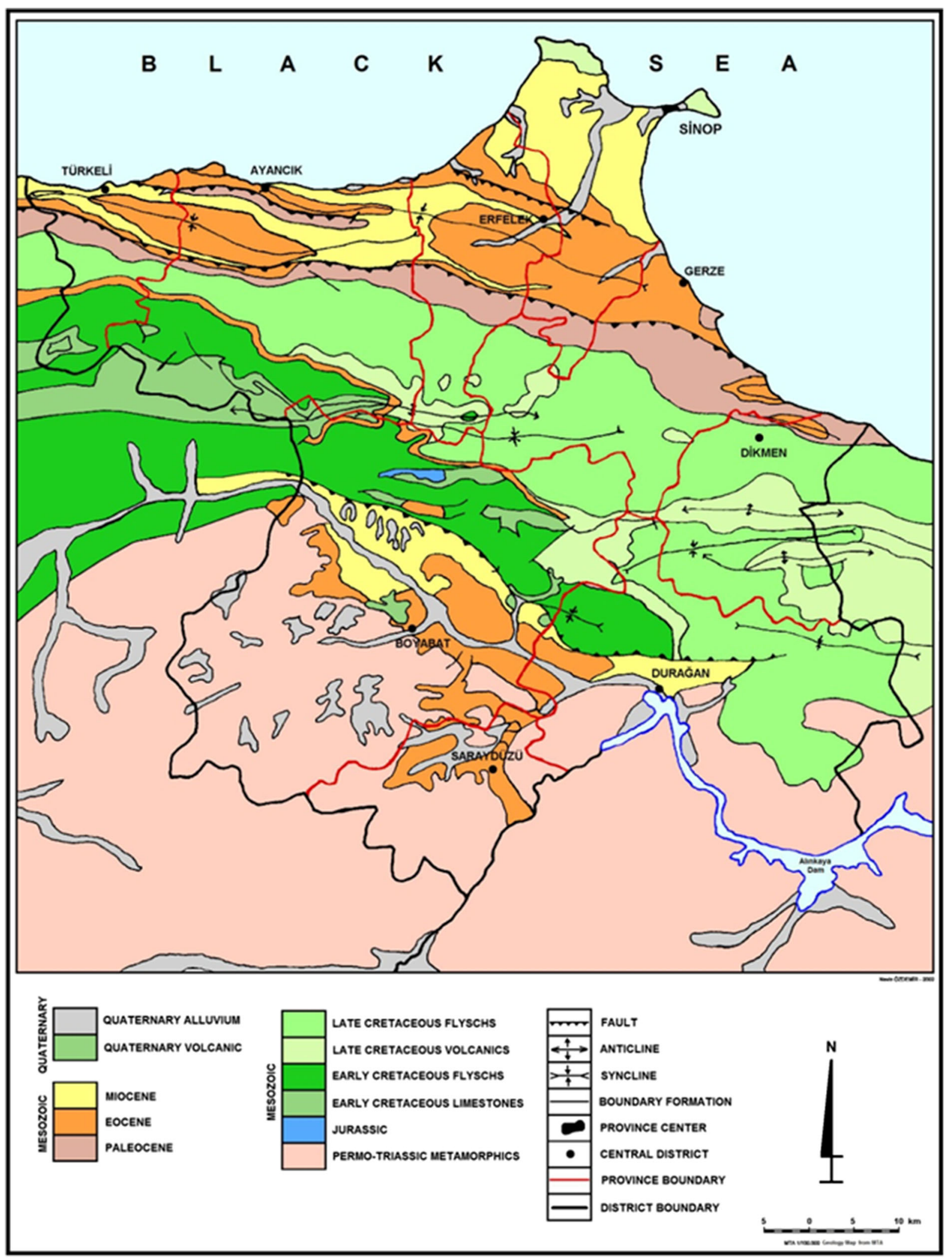

Figure 2. Geological map of Sinop region (Özdemir 2005).

institutions offered on different magnitude scales (body wave magnitude (Mb), duration magnitude $(\mathrm{Md})$, surface wave magnitude (Ms), and local magnitude $(\mathrm{Ml})$ ) constitutes important problems.
Considering that different institutions use different measurement devices and different calculation methods, earthquake magnitudes also become different. Therefore, conversion of magnitude scales 


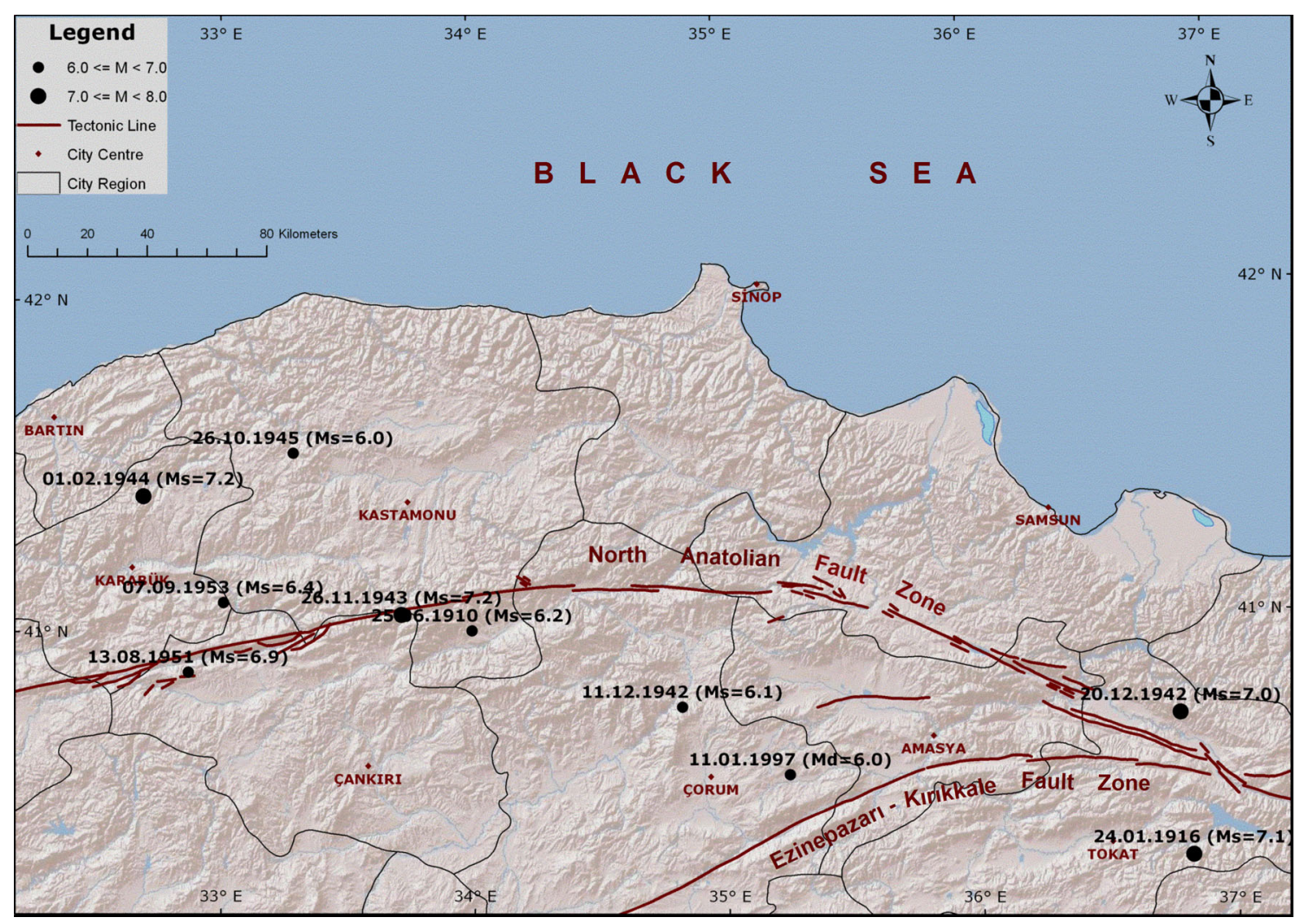

Figure 3. Active faults in the study area (Şaroğlu and ve Yılmaz 1987) and distribution of earthquakes with instrumental magnitudes 6.0 and higher in the study area between 1900 and 2008.

Table 1. There were 10 earthquakes with instrumental magnitudes 6.0 or higher in the region RTPMDEMP (2009a).

\begin{tabular}{|c|c|c|c|c|c|c|}
\hline Date & Time (GMT) & Latitude & Longitude & $\begin{array}{c}\text { Depth } \\
(\mathrm{km})\end{array}$ & Magnitude & Location \\
\hline 25.06 .1910 & 19:26:00.00 & 41.0000 & 34.0000 & 0 & $\mathrm{Ms}=6.2$ & Osmancık-Corum \\
\hline 24.01 .1916 & $06: 55: 00.00$ & 40.2700 & 36.8300 & 10 & $\mathrm{Ms}=7.1$ & Almus-Tokat \\
\hline 11.12 .1942 & 02:39:00.00 & 40.7600 & 34.8300 & 40 & $\mathrm{Ms}=6.1$ & Laçin-Çorum \\
\hline 20.12 .1942 & 14:03:00.00 & 40.7000 & 36.8000 & 16 & $\mathrm{Ms}=7.0$ & Erbaa-Tokat \\
\hline 26.11.1943 & $22: 20: 00.00$ & 41.0500 & 33.7200 & 10 & $\mathrm{Ms}=7.2$ & Tosya-Samsun \\
\hline 01.02 .1944 & 03:22:00.00 & 41.4100 & 32.6900 & 10 & $\mathrm{Ms}=7.2$ & Gerede-Bolu \\
\hline 26.10 .1945 & 13:56:00.00 & 41.5400 & 33.2900 & 50 & $\mathrm{Ms}=6.0$ & Daday-Kastamonu \\
\hline 13.08 .1951 & 18:33:00.00 & 40.8800 & 32.8700 & 10 & $\mathrm{Ms}=6.9$ & Kurşunlu-Çankiri \\
\hline 07.09 .1953 & 03:59:00.00 & 41.0900 & 33.0100 & 40 & $\mathrm{Ms}=6.4$ & Kurşunlu-Çankiri \\
\hline 11.01 .1997 & 06:42:00.30 & 40.5500 & 35.2500 & 10 & $\mathrm{Md}=6.0$ & Mecitözü-Çorum \\
\hline
\end{tabular}

into each other cannot be made with analytical methods. This situation requires the development of empirical equations. Standard least squares method and orthogonal regression methods are the most commonly used empirical relationships. Standard least square method only considers the error which is caused by random earthquakes. However, determination of earthquake magnitudes depends on many factors. For this reason, it is not possible to determine magnitudes without an error. In this case, using the orthogonal regression method is more appropriate which can also be used on the previous seismic hazard analysis studies conducted in Turkey. As a result of the analysis of earthquakes on nationwide scale in the last century with related method, the obtained conversion equations (Deniz and Yücemen 2005) are given below.

$$
\begin{aligned}
& M_{w}=2.25 x M_{B \text {-ave }}-6.14 \\
& M_{w}=1.27 x M_{D \text {-ave }}-1.12, \\
& M_{w}=1.57 x M_{L \text {-ave }}-2.66 \\
& M_{w}=0.54 x M_{S \text {-ave }}-2.81 .
\end{aligned}
$$


In equation (1), 'ave' sub-icon represents the average earthquake magnitudes given according to the same scale on different data sources for every earthquake.

There are several stochastic models which are considered dependent or independent to previous earthquakes on the estimation process of the earthquake occurrences. The Poisson model is the most widely used of these models. For earthquake events to build up a Poisson process, they must meet the following conditions first; earthquakes are independent in time, which means earthquake occurrences in any year does not affect re-occurrence. Earthquakes are independent in space. It means an earthquake which occurrs in any source area will not affect earthquake occurrence in another source area. There is zero possibility of being two separate earthquakes in the same place at the same time. According to Poisson model: the possibility of $n$ number earthquake that is bigger than $m_{0}$ lower magnitude limit in the studied area on $t$ time period is given with the equation below:

$$
P_{n}(t)=e^{-\lambda t} \cdot \frac{(\lambda t)^{n}}{n !}
$$

In this equation, $P_{n}(t)$ is the possibility of $n$ number event during the $t$ time, $n$ is the number of events and $\lambda$ is the number of earthquakes on unit time period (generally 1 year) in a studied area.

In this study, Poisson model was used. To ensure the independent condition of this model, preliminary earthquakes and aftershocks were excluded from the analysis. There are a lot of methods to separate the preliminary and aftershocks from the main shocks in the literature (Gardner and Knopoff 1974; Prozorov and Dziewonski 1982; Savage and Rupp 2000; Kagan 2002). Preliminary and aftershocks show similar spatial and temporal distributions around the main shocks. Based on the studies of Deniz and Yücemen (2005) in this study, all of the earthquakes inside a particular time and distance window are considered as aftershocks to a main shock which is recorded on a level of a particular earthquake magnitude. In assessing an earthquake as a preliminary earthquake, there must exist another, bigger magnitude earthquake inside the time and distance window identified for its own level of magnitude. This biggest magnitude earthquake is assumed as the main shock. As an exception, all the earthquakes whose magnitudes are higher than 6.0 inside the particular time and distance window are considered as main shocks. Time and distance windows (Deniz and Yücemen 2005) that are used in this study are given in table 2 .
Table 2. Time and distance windows used in the identification of aftershocks (Deniz and Yücemen 2005).

\begin{tabular}{lcr}
\hline Magnitude & $\begin{array}{c}\text { Distance } \\
(\mathrm{km})\end{array}$ & $\begin{array}{r}\text { Time } \\
(\text { day })\end{array}$ \\
\hline 4.5 & 35.5 & 42 \\
5.0 & 44.5 & 83 \\
5.5 & 52.5 & 155 \\
6.0 & 63.0 & 290 \\
6.5 & 79.4 & 510 \\
7.0 & 100.0 & 790 \\
7.5 & 125.9 & 1326 \\
8.0 & 151.4 & 2471 \\
\hline
\end{tabular}

\section{Seismic sources}

In this study, 101 earthquakes during the 18-year time period were used; 71 of these earthquakes (figure 4) were considered as main shocks. 37 earthquakes from these main shocks were identified as source zone earthquakes and 34 earthquakes were evaluated as background field source earthquakes (figure 4). Determined seismic source zones for the whole of Turkey by Deniz (2006) also were considered on the selection of the source zones earthquakes in this study (figure 4).

Although the study area is the Sinop central, it is obvious that seismic hazard cannot be dependent on earthquakes in the examined area. Therefore it is assumed that the earthquake hazard of the region was determined by rectangular area which was limited by $40.66^{\circ}-42.82^{\circ} \mathrm{N}$ and $32.20^{\circ}-36.55^{\circ} \mathrm{E}$. 23 seismic sources were identified within this region (figure 4).

To determine the probability distribution of earthquake magnitudes, the correlation proposed by Gutenberg and Richter (1949) is expressed as:

$$
\log N(M)=a-b(M) .
$$

In this correlation, $N$ is the number of earthquakes with $M$ magnitude or greater than $M$ in a year, $a$ and $b$ are regression coefficients and $M$ is the magnitude of the earthquake.

In the relationship of equation (2), a-coefficient is identified as 'Annual Average Index of Seismic Activity' which depends on the size of the region, duration of the observation and earthquake activity in the duration of the observation and $b$-coefficient is identified as 'Seismotectonic parameter' which varies according to the tectonic characteristics of the region.

Using the least square method for source zone and background field source earthquakes, $a$ and $b$ coefficients on equation (2) relationship were calculated separately for each source zone from the 


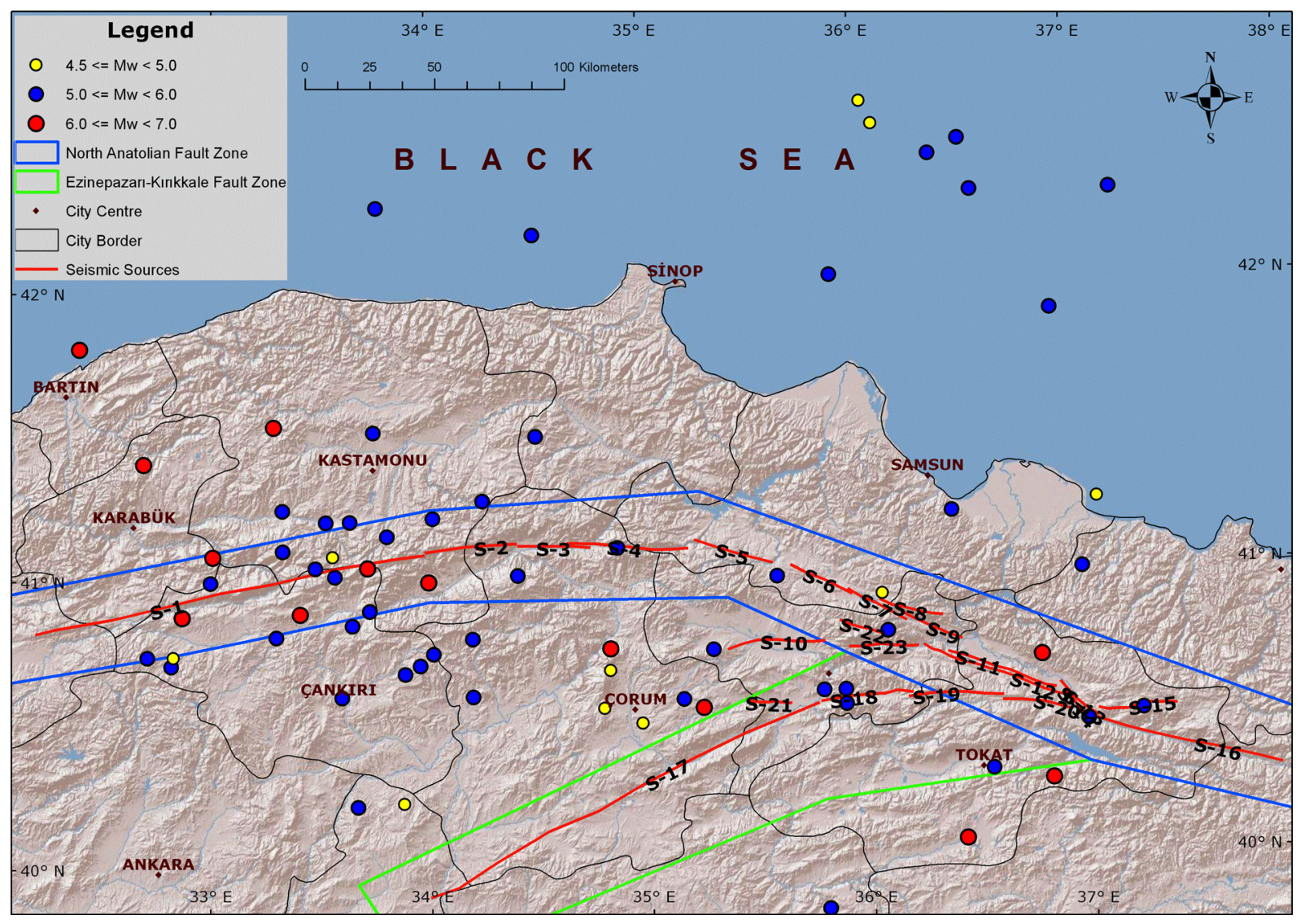

Figure 4. Main shocks in the study area, seismic sources are identified within this region and seismic source zones.

$M-\log N(M)$ curve (figure 5). High seismic activity in the region that corresponds to a small coefficient of $b$, shows that the voltage is discharged continuously. However, graph of the magnituderecurrence relation Ezinepazar-Kırıkkale fault source zone appears to be less than the amount of the earthquake (figure $5 \mathrm{~b}$ ).

\section{Attenuation relationship}

In this study, attenuation relationship proposed by Kalkan and Gülkan (2004) and Boore et al. (1997) was used. According to Kalkan and Gülkan (2004) and Boore et al. (1997) due to the use of equations of attenuation relations, the development of different faults according to the specifications is due to different ground conditions. Researchers recommend that in these kinds of studies coefficients for the different soil conditions in the same attenuation relationship should be used by changing. On the other hand, examination of local soil conditions of the area emerges as another subject of study. Thus, coefficients for the hard soil will be used for attenuation relationship in our study. Every attenuation relationship will be taken as $V s=700 \mathrm{~m} / \mathrm{s}$. Thereby results obtained from the attenuation relationships can be compared.

\subsection{Kalkan and Gülkan (2004)}

Kalkan and Gülkan included in their study done in 2004, moment magnitude values of 4.0 and greater of 57 earthquakes which occurred in Turkey between the years 1976 and 2003, the equation was obtained using the 223 horizontal component record from the 112 strong-motion measurement:

$$
\begin{aligned}
\ln Y= & 0.393+0.576\left(M_{W}-6\right)-0.107\left(M_{W}-6\right)^{2} \\
& -0.899 \ln (r)-0.200 \ln \left(V_{S} / V_{A}\right)
\end{aligned}
$$

where $Y$ is the horizontal component of the largest ground acceleration in terms of gravitational acceleration (in grams) and $M$ is the moment magnitude.

They identified the standard deviation of $\ln Y$ in terms of Peak Ground Acceleration (PGA) as $\sigma_{\ln Y}=0.612$. The variable $r$ is calculated using the following equation:

$$
r=\left(r_{c l}^{2}+h^{2}\right)^{\frac{1}{2}}, V_{A}=1112 \text { and } h=6.91
$$

where $r_{c l}$ is identified as the shortest distance in kilometers between the expected location of the largest ground acceleration with the projection of rupture surface to earth. The calculated values of other parameters in equation (3) are given in table 3 (figure 6). 


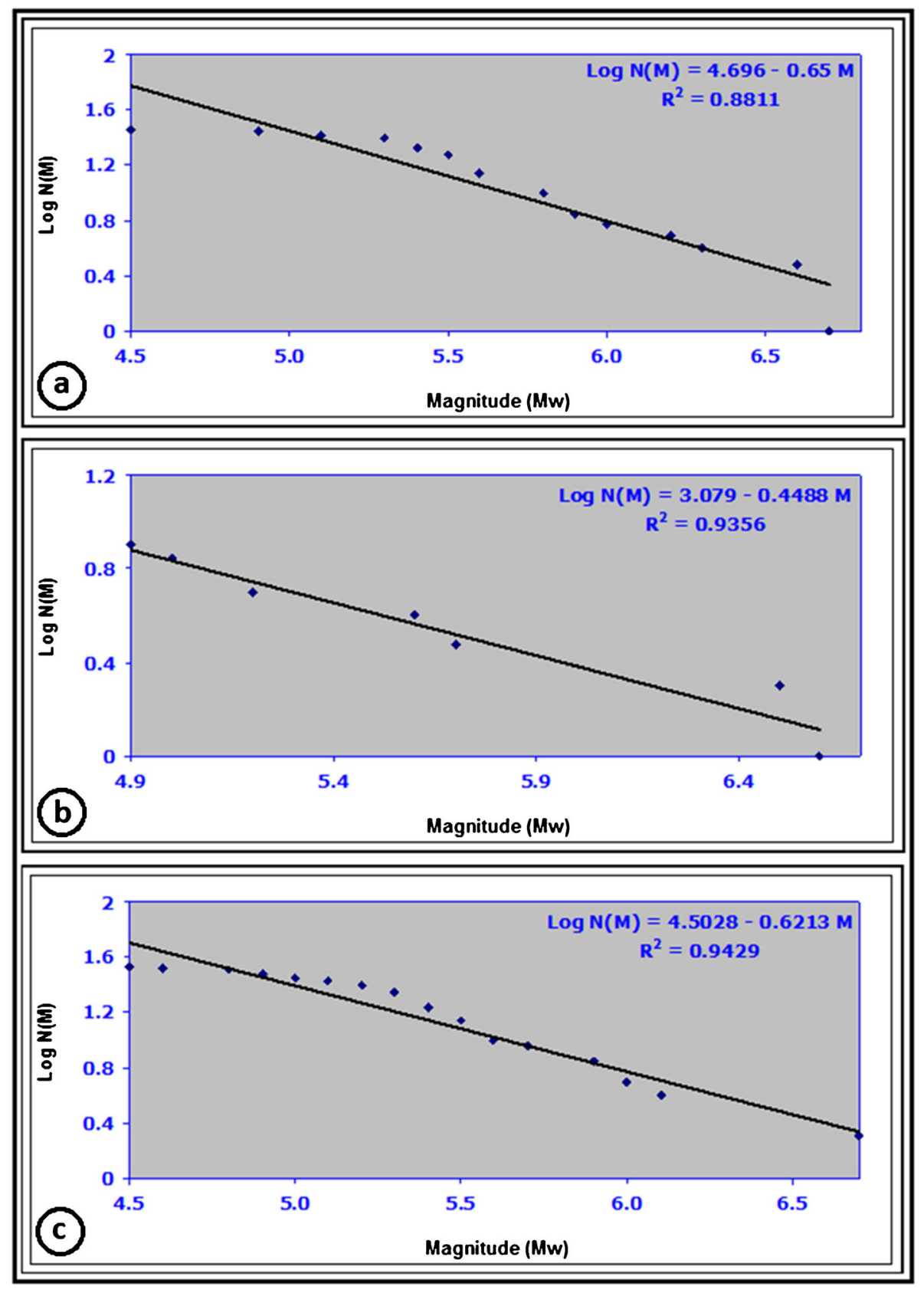

Figure 5. Magnitude-frequency relationship. (a) NAFZ source zone, (b) Ezinepazarı-Kırıkkale Fault source zone (EKFZ), and (c) Background source zone (BSZ).

Here average $V_{S}$ value for rock was taken to be $700 \mathrm{~m} / \mathrm{sec}$, for hard soil to be $400 \mathrm{~m} / \mathrm{sec}$ and for soft soil to be $200 \mathrm{~m} / \mathrm{sec}$ (Kalkan and Gülkan 2004).

\subsection{Boore et al. (1997)}

Boore et al. in their study done in 1997 included 271 records belonging to the 20 shallow focused earthquakes that occurred in North America between the years 1940 and 1992. Magnitudes of these earthquakes vary between 5.5 and 7.5 according to $\mathrm{Mw}$. However, a number of ground motion measurements caused by earthquakes smaller than 6.0 are limited. In the original study, alternative analyses were conducted which classified earthquakes according to their fault mechanism. However, in our study attenuation relationships obtained by using all the earthquakes with moment magnitudes of 4.0 and greater were given. Attenuation relationships suggested for hard soil up to $80 \mathrm{~km}$ are expressed as

$$
\begin{gathered}
\ln Y=b_{1}+b_{2}(M-6)+b_{3}(M-6)^{2} \\
+b_{5} \ln r+b_{v} \ln \left(\frac{V_{S}}{V_{A}}\right)
\end{gathered}
$$


Table 3. The coefficient values in attenuation relationships developed by Kalkan and Gülkan (2004) and Boore et al. (1997).

\begin{tabular}{|c|c|c|c|c|c|c|c|c|c|}
\hline Period (sec) & Developers & $b_{1}$ & $b_{2}$ & $b_{3}$ & $\mathrm{~b}_{5}$ & $\mathrm{~b}_{V}$ & $\mathrm{~V}_{A}$ & $\mathrm{~h}(\mathrm{~km})$ & $\sigma_{\ln Y}$ \\
\hline Peak ground & Kalkan and Gülkan (2004) & 0.393 & 0.576 & -0.107 & -0.899 & -0.200 & 1112 & 6.91 & 0.612 \\
\hline acceleration (PGA) & Boore et al. (1997) & -0.313 & 0.527 & 0.000 & -0.778 & -0.371 & 1396 & 5.57 & 0.495 \\
\hline
\end{tabular}

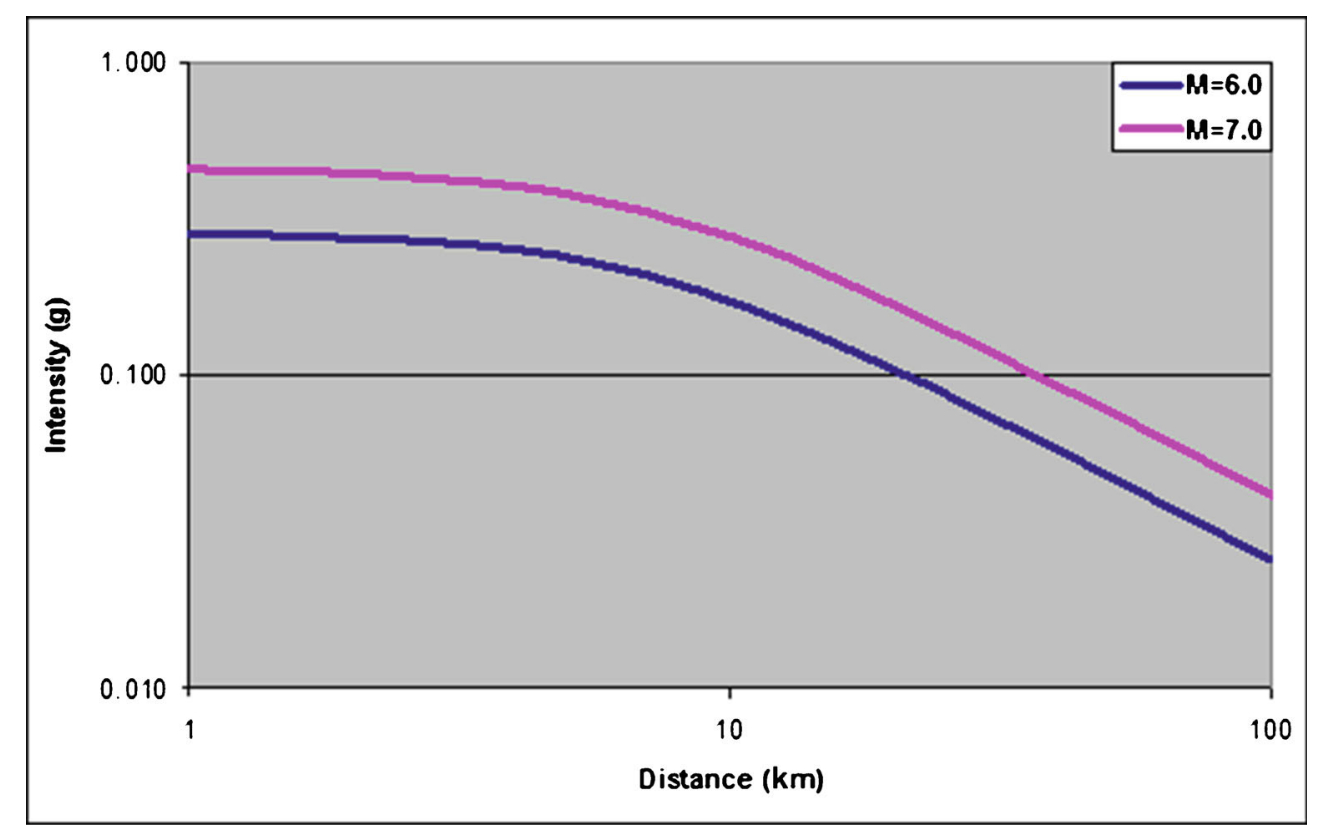

Figure 6. Peak ground acceleration values attenuation-relation proposed by Kalkan and Gülkan (2004).

where $Y$ is the horizontal component of the largest ground acceleration in terms of gravitational acceleration (in grams) and $M$ is the moment magnitude.

They were identified standard deviation of $\ln Y$ as $\sigma_{\ln Y}=0.495$. Boore et al. (1997 with_ erratum) variable is calculated with this equation below:

$$
r=\left(r_{c l}^{2}+h^{2}\right)^{\frac{1}{2}}
$$

In this equation, $r_{c l}$ is identified as the shortest distance in $\mathrm{km}$ between the expected location of the largest ground acceleration with the projection of rupture surface to earth. The calculated values of other parameters in equation (4) are given in table 3 (figure 7).

\section{Estimated seismic hazard values for Sinop province}

For making the analysis of seismic hazard in the study area and creating the iso-acceleration maps, a computer program CRISIS 2003 (Ordaz et al. 2003) was used. Using the different attenuation relationships, iso-acceleration maps were acquired for Sinop province corresponding to the recurring period of 475 years (Solomos et al. 2008). The program uses Poisson and characteristic earthquake models to consider the occurrence and distribution of earthquakes and the seismicity of the sources along with attenuation relationships to define the ground motion at the site. Civil engineers identified a situation concerning 50-year life proximity of the buildings. In this case, the economic life of a structure which has had 50 years of exposure to a major earthquake probability is 0.10. Seismic hazard maps are also plotted for PGA and MSK corresponding to a return period of 475 years (10\% probability of exceedance in 50 years) considering the combination composed of the most likely assumptions. These maps are shown in figures 8 and 9 . All of the seismic hazard calculations are conducted using the software CRISIS 2003.

\subsection{Kalkan and Gülkan (2004)}

The largest acceleration value calculated for the recurring period of 475 years was found to be $0.14 \mathrm{~g}$ at the Sinop city center. Acceleration value in south of the study area also was obtained as $0.40 \mathrm{~g}$ (figure 8). 


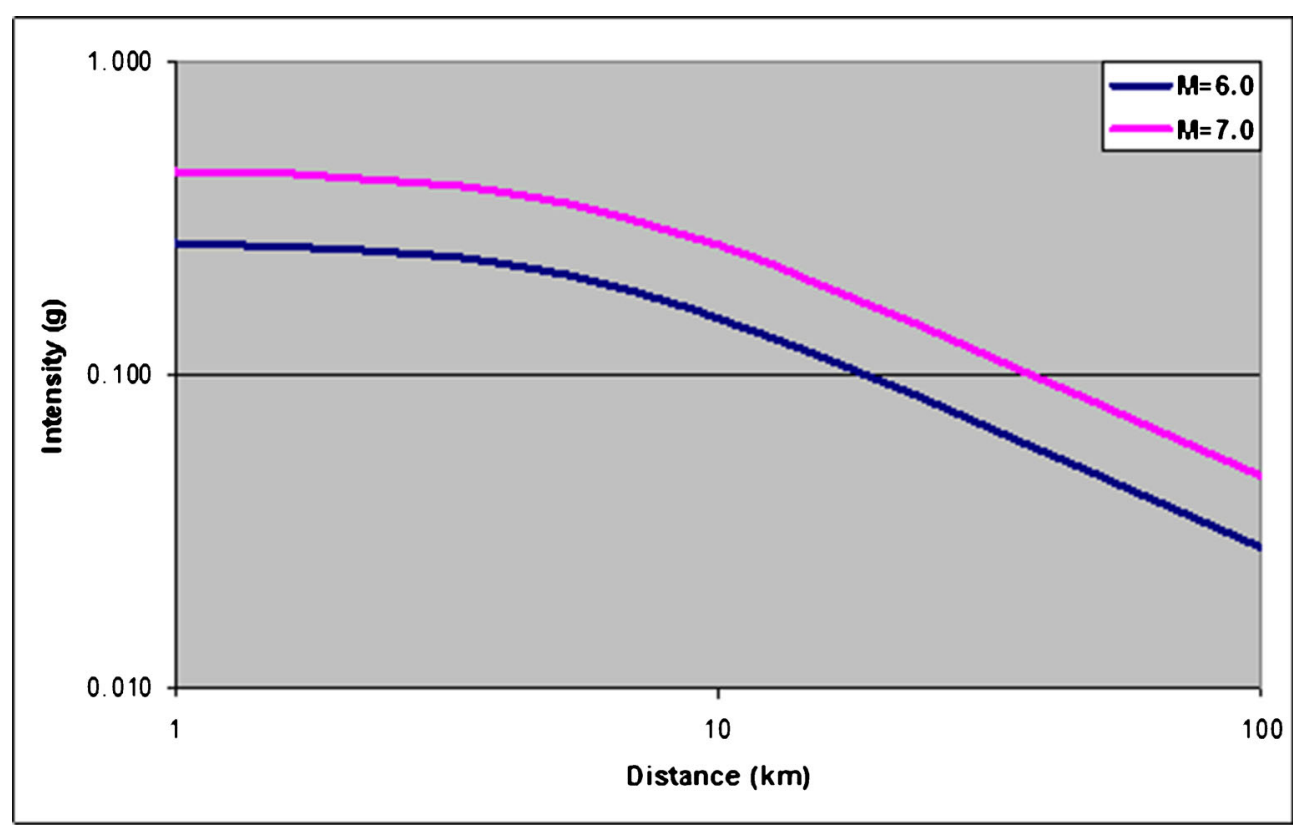

Figure 7. Peak ground acceleration values attenuation-relation proposed by Boore et al. (1997).

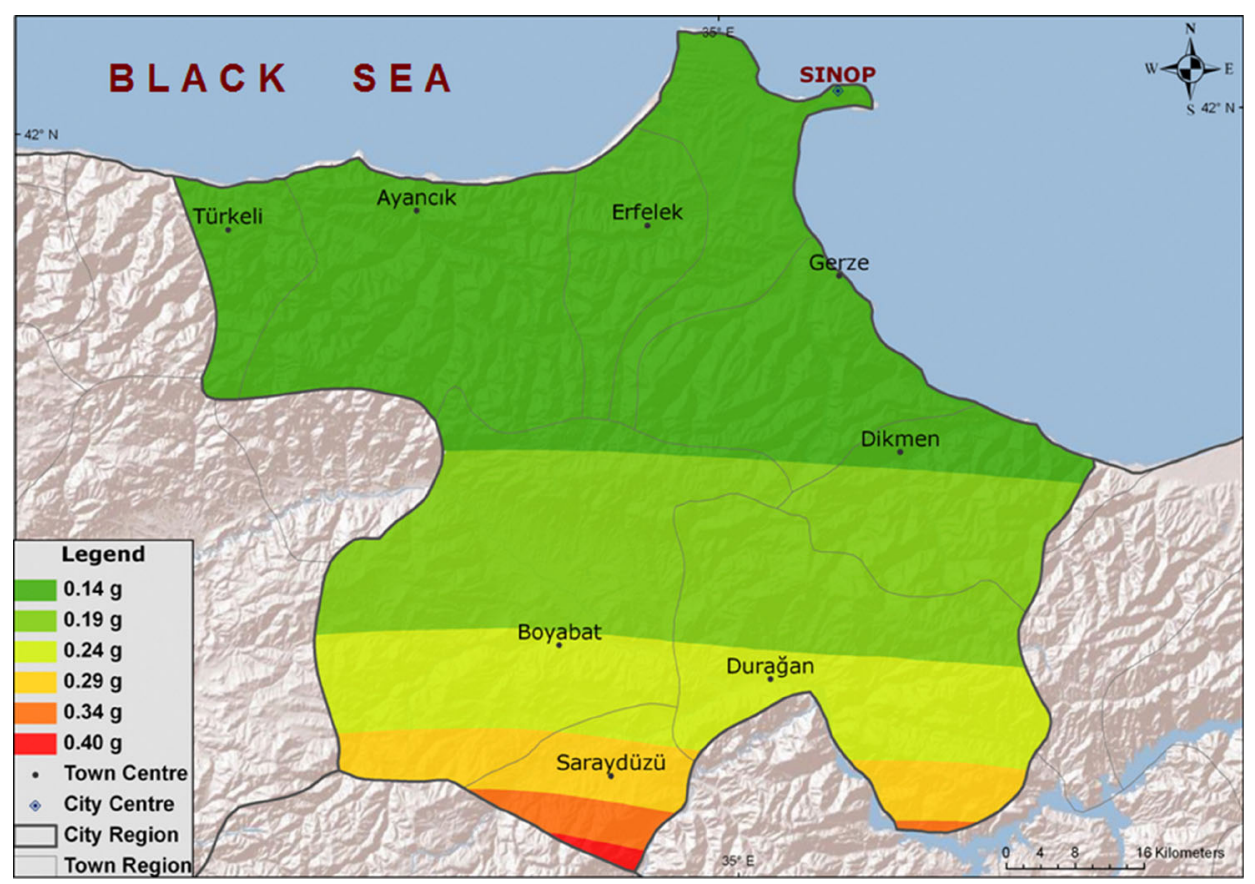

Figure 8. Iso-acceleration map of Sinop province corresponding to recurring period of 475 years calculated according to Kalkan and Gülkan (2004).

\subsection{Boore et al. (1997)}

The largest acceleration value calculated for the recurring period of 475 years was found to be $0.12 \mathrm{~g}$ at the Sinop city centre. This value increases southwards from city center and reaches $0.29 \mathrm{~g}$ in the area closest to the seismic source (figure 9).

Saraydüzü district is located in the closest proximity to NAFZ. Durağan district is located in the northeast of Saraydüzü and Boyabat district is located northwest of it. Seismic hazard analyses were made using the attenuation relationships by Boore et al. (1997) and Kalkan and Gülkan (2004) results are shown, respectively in figure 10. Saraydüzü district has more earthquake risk for the recurring period of 475 years considering Boyabat and Durağan districts. 


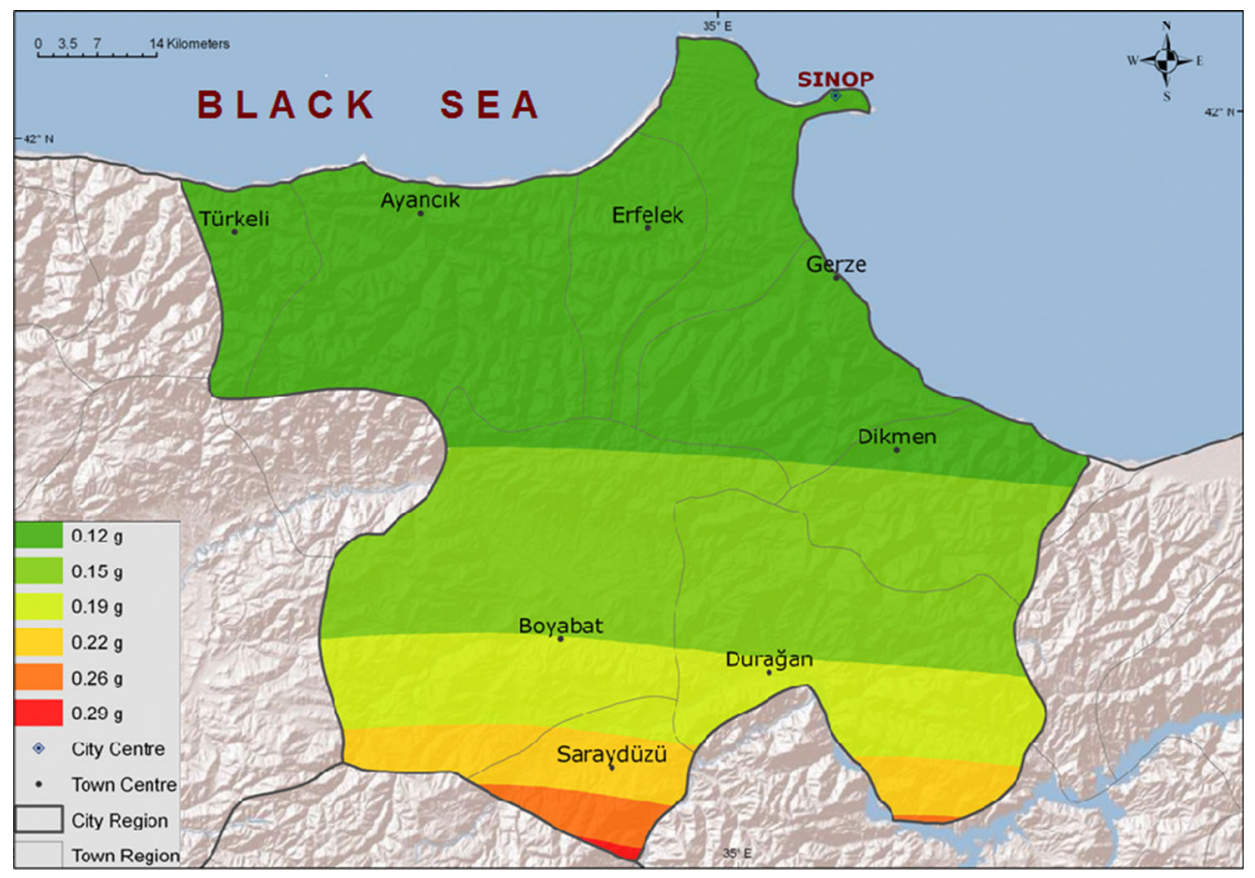

Figure 9. Iso-acceleration map of Sinop province corresponding to recurring period of 475 years calculated according to Boore et al. (1997).

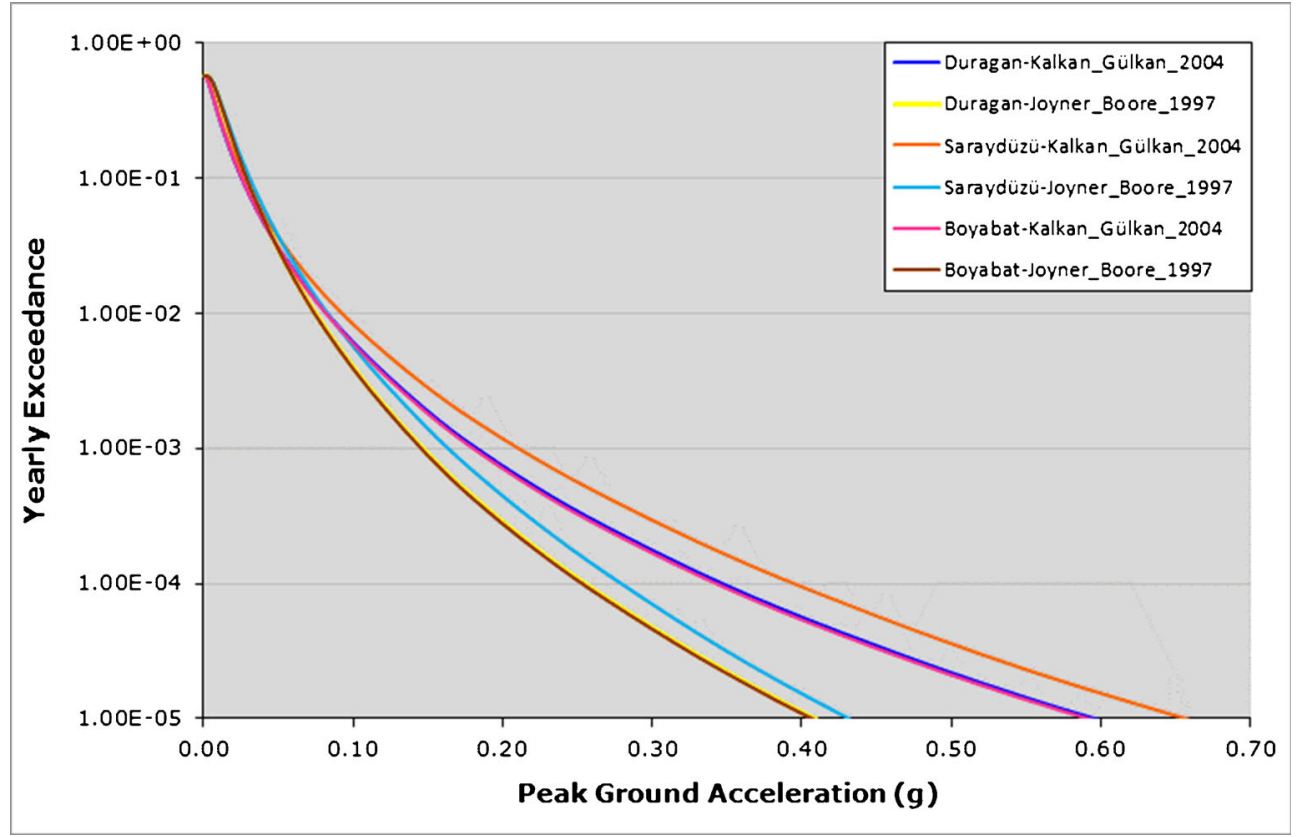

Figure 10. Calculated earthquake hazard curves for Boyabat, Durağan and Saraydüzü districts.

\section{Discussions and conclusions}

This study aims to estimate the earthquake hazard of Sinop province by using the probabilistic and statistical methods to study earthquakes whose instrumental magnitudes are 4.0 and greater occurring between the dates 1 January 1900 and 31 Decemeber 2008. The four stages of this procedure represent the characterization of seismic sources zones, estimation of seismic hazard parameters, selection of appropriate attenuation relationships, and evaluation of the hazard for the sites of interest. These seismic source models have been modified taking the advantage of recent 
neotectonic and seismic data for Sinop province. The previous studies performed by several researchers cover Sinop province.

We investigated 101 earthquakes that had instrumental magnitudes 4.0 and greater than 4.0 inside the 108-year period in our study area. 71 of these earthquakes were considered as the main shocks. 37 earthquakes were considered as the source zone earthquakes and the remaining 34 earthquakes were assessed as the background field source earthquakes. The data on historical and instrumentally recorded earthquakes for Sinop province and surrounding vicinity, collected from the Earthquake Research Department of the General Directorate of Disaster Affairs of Turkey (RTPMDEMP 2009b) were considered as a basis of seismic hazard calculations.

Four seismic sources were selected to assess the seismic hazard of Sinop. These are NAFZ, EKFZ, and BFZ, which are illustrated in figure 5. As a result, nationwide analysis of earthquakes in the last century obtained conversion equations (Deniz and Yücemen 2005). The Turkish specification suggests that the data defined above should be used for seismic studies of large engineering structures. The coefficients of the G-R law between magnitudes and their cumulative frequencies of occurrence.

In this study, attenuation relationships by Boore et al. (1997) and Kalkan and Gülkan (2004) were used. Seismic hazard curves corresponding to the recurring period of 475 years for the Sinop central, Saraydüzü, Boyabat and Durağan districts according to two attenuation relationships were obtained. According to these attenuation relationships, the correlation given by Kalkan and Gülkan (2004) between the calculated acceleration values for Sinop center, Saraydüzü, Boyabat and Durağan districts suggests a large quantity.

For Sinop central:

Attenuation relationship

Largest acceleration value corresponding to recurrence period of 475 years $(\mathrm{g})$

\begin{tabular}{ll}
\hline Boore et al. (1997) & 0.12 \\
Kalkan and Gülkan (2004) & 0.14 \\
\hline
\end{tabular}

For Saraydüzü district:

Attenuation relationship

Largest acceleration value corresponding to recurrence period of 475 years $(\mathrm{g})$

Boore et al. (1997)

$0.19-0.29$

Kalkan and Gülkan (2004)

$0.24-0.40$
For Boyabat district:

\begin{tabular}{lc}
\hline Attenuation relationship & $\begin{array}{l}\text { Largest acceleration } \\
\text { value corresponding } \\
\text { to recurrence period } \\
\text { of } 475 \text { years }(\mathrm{g})\end{array}$ \\
\hline Boore et al. $(1997)$ & $0.12-0.22$ \\
Kalkan and Gülkan (2004) & $0.14-0.29$ \\
\hline
\end{tabular}

For Durağan district:

\begin{tabular}{lc}
\hline Attenuation relationship & $\begin{array}{l}\text { Largest acceleration } \\
\text { value corresponding } \\
\text { to recurrence period } \\
\text { of } 475 \text { years }(\mathrm{g})\end{array}$ \\
\hline Boore et al. $(1997)$ & $0.15-0.22$ \\
Kalkan and Gülkan (2004) & $0.19-0.34$ \\
\hline
\end{tabular}

Using two different attenuation relationships, the largest ground acceleration corresponding to the recurrence period of 475 years is found to be $0.14 \mathrm{~g}$ for bedrock on the central district. When computing the seismic hazard curves of other mentioned districts, it can be said that Saraydüzü district has greater probability of seismic hazard than other districts.

Based on the probabilistic seismic hazard analysis, the following conclusions are drawn: The attenuation models introduced by Boore et al. (1997) and Kalkan and Gülkan (2004) gave more realistic solutions for the Sinop province and its vicinity. For the province of Sinop, the hazard is mainly dominated by NAFZ. The analyses indicate that the mean PGA value for the city center of Sinop is about $0.12 \mathrm{~g}$ by Boore et al. (1997) and $0.14 \mathrm{~g}$ by Kalkan and Gülkan (2004) $10 \%$ probability of exceedance in 50 years. The seismic hazard maps produced by this study agree with the one prepared by the National Disaster Organization for the whole country, but it provides more detailed values for the investigated region.

\section{References}

Abrahamson N A and Silva W J 1997 Empirical response spectral attenuation relations for shallow crustal earthquakes; Seismol. Res. Lett. 68(1) 94-127.

Akın H 1978 Geologie, magmatismus und Lagerstattenbildung im Ostpontischen Gebirge-Türkei aus der sicht der platten tektonik; Geol. Rdsch. 68(1) 253-283.

Ambraseys N N 1990 Uniform magnitude reevaluation of European earthquakes associated with strong-motion records; Earthq. Eng. Struct. Dyn. 19 1-20.

Bansal A R, Dimri V P and Babu K K 2012 Epidemic Type Aftershock Sequence (ETAS) Modeling of Northeastern Himalayan seismicity; J. Seismol, doi: 10.1007/s10950-012-9314-7.

Bansal A R and Ogata Y 2010 Seismicity activation before the mega-earthquake of 26 December 2004 based on 
epidemic type aftershock sequence (ETAS) model, AGU Fall Meeting, Abstract 1, 2084.

Boore D M, Joyner W B and Fumal T E 1997 Equations for estimating horizontal response spectra and peak acceleration from western North American earthquakes: A summary of recent work; Seismol. Res. Lett. 68(1) 128-153.

Chiaruttini C and Siro L 1981 The correlation of peak ground horizontal acceleration with magnitude, distance, and seismic intensity for Friuli and Ancona, Italy, and the Alpide belt; Bull. Seismol. Soc. Am. 71 1993-2009.

Cornell C A 1968 Engineering seismic risk analysis; Bull. Seismol. Soc. Am. 58 1583-1606.

Deniz A and Yücemen M S 2005 Assessment of seismic hazard for the Antalya region using stochastic methods (in Turkish); Proceedings, Congress on the Civil Engineering Problems of the Antalya Region, pp. 540-551.

Deniz A 2006 Estimation of earthquake insurance premium rates based on stochastic methods; Middle East Technical University (METU), Department of Civil Engineering. M.Sc.Thesis.

Dewey J F and Bird J M 1970 Mountain belts and new global tectonics; J. Geophys. Res. 75 2625-2638.

Eğin D and Hirst D M 1979 Tectonic and magmatic evolution of volcanic rocks from the Northern Harşit river area, Pontid volcanic province, northeast Turkey; J. Volcan. Geoth. Res. 6 105-123.

Ercan T and ve Gedik A 1983 Volcanism of the Pontide Belt (in Turkish); Jeoloji Mühendisliği 18 3-22.

Ercan T, Yergök F, İplikçi E, Deveciler E and Keskin İ 1983 Ereğli (Zonguldak) çevresindeki ada yayı volkanizmasının özellikleri; Jeomorfoloji Derg. 12 81-105.

Gardner J K and Knopoff L 1974 Is the sequence of earthquakes in southern California, with aftershocks removed, Poissonian?; Bull. Seismol. Soc. Am. 64 1363-1367.

Gasperini P and Ferrari G 2000 Deriving numerical estimates from descriptive information: The computation of earthquake parameters; Ann. Geofis. 43 729-746.

Gedikoğlu A 1978 Harit granit complex and neighbouring rocks (Giresun-Doğankent): Thesis (unpublished), Black Sea Technical University, Trabzon, Turkey.

Gedikoğlu A, Pelin S and ve Özsayar T 1979 The main lines of geotectonie development in the East Pontids in the Mesozoic areas; Geoeome-I Conference Proceedings, pp. $555-580$.

Gedikoğlu A, Pelin S and ve Özsayar T 1982 Gölköy (Ordu) yöresinde bir paleokaldera ile cevherlemelerin konumu arasındaki ilikiler; KTÜ Yerbilimleri Derg. 2(1-2) 117130.

Genç G 2004 Probabilistic seismic hazard assessment for Eskişehir, METU, Graduate School of Natural and Applied Sciences, Master thesis, 154p.

Giardini D, Di Donato M and Boschi E 1997 Calibration of magnitude scales for earthquakes of the Mediterranean; J. Seismol. 1 161-180.

Gutdeutsch R, Kaiser D and Jentzsch G 2002 Estimation of earthquake magnitudes from epicentral intensities and other focal parameters in central and southern Europe; Geophys. J. Int. 151(2) 824-834.

Gutenberg B and Richter C F 1949 Seismicity of the Earth and Associated Phenomenon; Princeton University Press, Princeton, New York.

International Seis. Center 2009 http://www.isc.ac.uk, Internatl. Seis. Cent., Thatcham, United Kingdom.

Johnston A C 1996 Seismic moment assessment of earthquakes in stable continental regions I. Instrumental seismicity; Geophys. J. Int. 124 381-414.

Kagan Y Y 2002 Aftershock zone scaling; Bull. Seismol. Soc. Am. 92(2) 641-655.
Kalkan E and Gülkan P 2004 Site-dependent spectra derived from ground motion records in Turkey; Earthquake Spectra 20(4) 1111-1138.

Kramer S L 1996 Geotechnical Earthquake Engineering; Prentice Hall, New Jersey, 653p.

Lolli B and Gasperini P 2012 A comparison among general orthogonal regression methods applied to earthquake magnitude conversions; Geophys. J. Int. 190(2) 11351151.

Ogata Y 1988 Statistical models for earthquake occurrences and residual analysis for point processes; J. Am. Statis. Assoc. 83 9-27.

Ogata Y 2011 Pre-seismic anomalies in seismicity and crustal deformation: Case studies of the 2007 Noto Hanto earthquake of M6.9 and the 2007 Chuetsu-Oku earthquake of M6.8 after the 2004 Chuetsu earthquake of M 6.8; Geophys. J. Int. 186 331-348, doi: 10.1111/j.1365-246X.201.05033.x.

Ordaz M, Aguilar A and Arboleda J 2003 CRISIS2003, Ver. 1.2.100, Program for Computing Seismic Hazard, Instituto de Ingeniería, UNAM, Mexico.

Özdemir N 2005 One of the effective natural disaster in Sinop: The landslide; Dicle University Ziya Gökalp Faculty of Education 5 67-106.

Özsayar T, Pelin S, Gedikoğlu A, Eren A and ve Çapkınoğlu. Ş 1982 The geology of the Ardanuç (Artvin) region; KTÜ Yerbilimleri Derg. 2(1-2) 21-37.

Peccerillo A and Taylor S R 1975 Geochemistry of Upper Cretaceous volcanic rocks from the Pontic chain, northern Turkey; Bull. Volcan. 39 1-13.

Peccerillo A and Taylor S R 1976 Geochemistry of Eocene calc-alcaline volcanic rocks from Kastamonu area, Northern Turkey; Contrib. Mineral. Petrol. 68 63-81.

Polat O, Gök E and Yılmaz D 2008 Earthquake hazard of the Aegean Extension Region (West Turkey); Turkish J. Earth Sci. 17 593-614.

Prozorov A G and Dziewonski A M 1982 A method of studying variations in the clustering property of earthquakes: Application to the analysis of global seismicity; J. Geophys. Res. 87(B4) 2829-2839.

Rangin C, Bader A G, Pascal G, Ecevitolu B and Görür N 2002 Deep structure of the Mid Black Sea High (offshore Turkey) imaged by multi-channel seismic survey (BLACKSIS cruise); Mar. Geol. 182 265-278.

RTPMDEMP 2009a Republic of Turkey Prime Ministry Disaster and Emergency Management Precidency Earthquake database, Ankara.

RTPMDEMP 2009b Specification for structures to be built in disaster areas, Disaster and Emergency Management Presidency, Ankara.

Sadigh K, Chang C Y, Egan J A, Makdisi F and Youngs R R 1997 Attenuation relationships for shallow crustal earthquakes based on California strong motion data; Seismol. Res. Lett. 68(1) 180-189.

Savage M K and Rupp S H 2000 Foreshock probabilities in New Zealand, New Zealand; J. Geol. Geophys. 43 461-469.

Selçuk A S and Yücemen M S 2000 Reliability of lifeline networks with multiple sources under seismic hazard; Natural Hazards, Kluwer Academic Publishers, 21 1-18.

Solomos G, Pinto A and Dimova S 2008 A review of the seismic hazard zonation in National Building Codes in the Context of Eurocode 8, Support to the Implementation, Harmonization and Further Development of the Eurocodes, JRC European Commission.

Stojanov R 1973 Pontidler'de Harit nehri sahasında volkanik talarm petrolojisi: Cumhuriyetin 50; yılı Yerbilimleri Kongresi Tebliğler kitabı, pp. 490-517. 
Stromeyer D, Grünthal G and Wahlström R 2004 Chisquare regression for seismic strength parameter relations, and their uncertainties, with applications to an Mw based earthquake catalogue for central, northern and northwestern Europe; J. Seismol. 8(1) 143153.

Şaroğlu F and ve Yılmaz Y 1987 Doğu Anadolu'da neotektonik dönemdeki jeolojik evrim ve havza modelleri; $M T A$ Derg. 107, Ankara.

Şengör A M C and Yllmaz Y 1981 Tethyan evolution of Turkey. A plate tectonic approach; Tectonophys. 75 181241.

Şengör A M C 1982 Kimmerid orojenik sisteminin evrimi, Orta Mesozoyikte Paleo-Tetisin kapanması olayı ve ürünleri; Türkiye Jeoloji Kurultayı Bildiri özetleri Kitabı, pp. $45-46$.
Tokel S 1972 Stratigraphical and history of the Gümüşhane area, NE Turkey; University of London, University Collage, Ph.D. Thesis.

Tokel S 1973 Doğu Pontidler'in Mesozoyik ve Tersiyerdeki geliimleri, bu gelişmelerin Kuzey Anadolu sismik zonu ile muhtemel ilgileri: Cumhuriyetin 50; Yılı Yerbilimleri Kongresi Tebliğler kitabı, pp. 1-4.

Tokel S 1977 Eocene calc-alkaline andesites and geotectonism in the eastern Black Sea region; Türkiye Jeol. Kur. Bült 20 49-54.

Tokel S 1981 Plaka tektoniğinde magmatik yerleimler ve jeokimya Türkiye'den örnekler; Yeryuvarı ve İnsan 6(2) $53-65$.

Yılmaz O 1980 Daday-Devrekani masifi kuzeydoğu kesimi litostratigrafik birimleri ve tektoniği; Yerbilimleri Derg 5-6 101-135, Ankara.

MS received 7 June 2012; revised 21 February 2013; accepted 24 February 2013 